\title{
EDITORIALS
}

\section{Bretylium: A prototype for future development of antidysrhythmic agents}

\author{
Eugene Patterson, Ph.D., and Benedict R. Lucchesi, Ph.D., M.D. Ann Arbor, Mich.
}

\section{THE CLINICAL PROBLEM-SUDDEN CORONARY DEATH}

The management of ventricular rhythm disorders and the prevention of sudden coronary death continue to be a major challenge for both the clinician and basic scientist. There is little doubt, from the very suddenness of and the ECG observations preceding or accompanying sudden coronary death, that cardiac arrhythmias are the cause of this event-either ventricular asystole or ventricular fibrillation. In view of the incidence of sudden death in patients with coronary artery disease, effective therapeutic interventions would be desirable in those who are demonstrated to be at high risk. In addition, patients who have high risk of coronary artery and left ventricular characteristics for developing a recurrent episode, need to be placed on prophylactic medical therapy. Thus survivors of myocardial infarction and that identifiable segment of the asymptomatic population with an ominous risk profile are demonstrably at very high risk of sudden death with at least two thirds of the deaths occurring in the first hour. ${ }^{1}$ There is ample evidence ${ }^{2}$ attesting to the fact that sudden death is reversible. However, if an impact is to be made upon the high mortality due to sudden coronary death, it must depend upon the recognition and treatment of those at risk with the goal of preventing ventricular fibrillation by a prophylactic therapeutic regimen. In reviewing the results of long-term suppressive therapy for the prevention of sudden coronary death, Lovell" stated that "nonspecific long-term use of existing drugs holds less promise than appeared at one time to be the case. It may be that tolerable drugs which are highly effective in inhibiting ven-

From the University of Michigan Medical School, Department of Pharma cology

Received for publication .Jan. 7.1983 ; accepted Jan. 20, 198:3.

Reprint requests: Benedict R. Lucchesi. M.D., Dept. of Pharmacology, M6:32! Medical Science Bldg. I, University of Michigan Medical School. Ann Arbor, MI 18109 tricular fibrillation when given long-term will be developed, and this is a worthwhile aim."

\section{AVAILABLE THERAPEUTIC INTERVENTIONS}

At present the antiarrhythmic drugs available in the United States for chronic management of patients with life-threatening arrhythmias are: quinidine, procainamide, disopyramide, propranolol, timolol, and phenytoin. None is considered suitable for long-term prophylactic use in the prevention of sudden coronary death. ${ }^{3}$ Of the new agents, aprindine, tocainide, mexiletine, encainide, ethmozin, flecainide, lorcainide, propafenone, pirmenol, verapamil, and diltiazem-none is known specifically to prevent ventricular fibrillation in either the experimental animal or in humans. In view of the long-term recognition of the primary role of ventricular fibrillation in sudden coronary death, it is most disappointing to note that the newer antiarrhythmic drugs were not developed specifically for the problem under consideration, but are drugs that were in use in other countries or were discovered as part of a routine antiarrhythmic screen and were subjected subsequently to clinical studies. There are limited animal data with respect to these agents and already several are proving to have serious toxic effects. ${ }^{4}$ The approach to finding an effective antifibrillatory drug in contrast to an antiarrhythmic drug for the prevention of sudden coronary death has been one of mere chance alone and it is doubtful that this "hit-and-miss" method will ever prove successful.

The almost "explosive" appearance of new class I antiarrhythmic agents which are effective in reducing the frequency of premature ventricular depolarizations but which lack specificity with respect to antifibrillatory activity, makes it unlikely that the current approach to identifying an agent capable of preventing sudden cardiac death will provide a solution to the problem at hand. The recent introduction of bretylium into clinical cardiology, however, has suggested a new approach to the prevention 
of life-threatening ventricular dysrhythmias. Although the precise mechanism of its antifibrillatory action is not known, the effects of bretylium on the cellular electrophysiology of the heart have been studied and have been noted to differ from those of the class I antiarrhythmic drugs.

Bretylium has been classified as belonging to a group of agents which are placed in class III because they have the property of increasing the action potential duration and prolonging the effective refractory period. Other members of this class include amiodarone, sotalol, pranolium, and clofilium. In the ischemic heart, bretylium decreases the disparity in action potential duration that exists between normal and ischemic regions. ${ }^{5}$ This action may account for the ability of bretylium to prevent the establishment of a reentry pathway and therefore to protect against the initiation of ventricular fibrillation.

The recent interest in bretylium as a potential agent for the suppression of recurrent ventricular tachyarrhythmias and recurrent ventricular fibrillation is highlighted in the May and June, 1983, issues of THE Journal, in which four groups of investigators report on the electrophysiologic and antidysrhythmic actions of the quaternary ammonium compound. Two of the papers report on the inability of bretylium to prevent the induction of sustained ventricular tachycardia by programmed electrical stimulation in patients known to be at risk of developing potentially lethal ventricular dysrhythmias. The first of these studies by Bauernfeind et al. ${ }^{6}$ employed programmed electrical stimulation in a patient population known to have had sustained ventricular tachycardia and/or ventricular fibrillation and who responded to programmed electrical stimulation with the induction of sustained ventricular tachycardia. All patients in this study were reported to have stable organic heart disease. The intravenous administration of bretylium was followed within 30 minutes by repeat testing with programmed electrical stimulation with 9 of the 10 patients failing to show any degree of benefit.

The second paper by Greene et al. ${ }^{7}$ examines the efficacy of bretylium after 4 to 9 days of continuous intravenous drug infusions in five patients with recurrent, life-threatening ventricular arrhythmias and in whom the disturbances in cardiac rhythm were not related to acute ischemia. All patients had inducible ventricular tachycardia and/or ventricular fibrillation which was not prevented by bretylium given as a continuous infusion at the rate of 2.3 $\mathrm{mg} / \mathrm{min}$ for a minimum of 4 days and a maximum of 9 days. It should be noted that in each of the studies cited, the patients had failed to exhibit beneficial effects from other antiarrhythmic drugs when assessed through the use of programmed electrical stimulation. In the latter report by Greene et al., ${ }^{7}$ a mean of 6.8 agents was used per patient before resorting to the use of intravenous bretylium.

\section{INDIRECT AND DIRECT CARDIAC ACTIONS OF BRETYLIUM}

In both animals and humans, the acute single dose administration of bretylium leads to a biphasic cardiovascular response. ${ }^{8-10}$ An initial release of norepinephrine from adrenergic nerve endings is accompanied by an acute rise in arterial pressure and heart rate. Within 20 to 30 minutes blood pressure, vascular resistance, and heart rate begin to decrease as peripheral sympathetic tone declines secondary to the adrenergic neuronal blocking effects of bretylium. These latter effects predominate during the chronic phase of therapy and may be circumvented by the previous administration of a tricyclic antidepressant agent which would block the neuronal amine pump which transports bretylium into the adrenergic neurone, thereby preserving adrenergic sympathetic tone without altering the electrophysiologic and therapeutic effects of bretylium upon the myocardium. ${ }^{10,11}$ It is important to recognize that despite the presence of adrenergic neuronal blockade, intermittant and/or continuous administration of bretylium will lead to a repeated or sustained release of neuronal stores of norepinephrine. The acute administration of bretylium and the associated release of catecholamines is accompanied by a reduction in both the action potential duration ${ }^{5}$ and myocardial refractoriness ${ }^{12}$ in normal ventricular myocardium. Furthermore, as a result of the associated catecholamine release from adrenergic nerve endings, the acute administration of bretylium often is accompanied by transient worsening of the cardiac rhythm. ${ }^{13}$ The failure to achieve a satisfactory response during the initial early period of treatment with bretylium could be attributed to the fact that there is a delay in onset of action after the drug is administered by a continuous intravenous infusion and/or the associated release of catecholamines exerts an arrhythmogenic effect which predominates over the direct electrophysiologic actions of the quaternary ammonium compound. The existence of this latter mechanism is supported by the ability of propranolol $(0.1 \mathrm{mg} / \mathrm{kg})$ to enhance the ability of bretylium to prevent reentrant ventricular arrhythmias in the canine heart. $^{13}$

In a recent study by Anderson et al., ${ }^{14}$ bretylium 
was administered as an initial dose of $5 \mathrm{mg} / \mathrm{kg}$ intravenously over a period of 15 minutes followed by a maintenance infusion of $1.5 \mathrm{mg} / \mathrm{min}$ for up to 90 minutes. There was no significant change in intracardiac conduction, although there was a decrease in the cardiac muscle refractory period during the 75 to 90 minutes of drug administration. These findings were to be expected after drug loading, as they are typical of changes associated with catecholamine stimulation of the heart. However, the continued refractory period shortening and facilitation of atrial and AV nodal conduction with no change in HisPurkinje and intraventricular conduction after 75 to 90 minutes of drug therapy were unexpected initially in view of earlier studies on isolated heart muscle and Purkinje fiber preparations, ${ }^{5.15,16}$ in which the effective refractory periods were prolonged-effects known to be independent of endogenous catecholamine release.

More recent studies with bretylium have confirmed direct electrophysiologic actions during chronic therapy, but have noted adrenergic, not direct actions, during acute therapy. ${ }^{12,17,18}$ We determined the kinetics of the antifibrillatory effects of bretylium and assessed the relative importance of myocardium us serum drug concentrations in 32 dogs after they received rapid infusions of bretylium $(6 \mathrm{mg} / \mathrm{kg}$ or $2 \mathrm{mg} / \mathrm{kg})$ or saline solution. ${ }^{18}$ Parallel determinations were made of drug concentrations in serum and myocardium, together with antifibrillatory and cardiac electrophysiologic effects, both with and without 2 minutes of regional myocardial ischemia produced by temporary coronary artery ligation. Serum bretylium concentration decreased rapidly after intravenous injection, whereas myocardial concentrations increased gradually, peaking at 1.5 to 6 hours. The ratio of myocardial to serum drug concentration increased from 6.4 to 12.6 at 12 hours. Parallel eliminations of the drug in serum and myocardium occurred thereafter, with an elimination half-life of 10.5 hours. Electrophysiologic and antifibrillatory effects paralleled myocardial rather than serum drug kinetics with peak effects at 3 to 6 hours. The ventricular effective refractory period was 24 to 26 msec greater at 3 hours in dogs treated with the drug than in those receiving saline solution. The ventricular fibrillation threshold increased sixto tenfold within 3 to 6 hours in dogs receiving 2 $\mathrm{mg} / \mathrm{kg}$ of bretylium. The average increase in threshold exceeded twelvefold after administration of 6 $\mathrm{mg} / \mathrm{kg}$ of bretylium. The repetitive ventricular response threshold 3 hours after drug administration increased fivefold after $2 \mathrm{mg} / \mathrm{kg}$ and eighteen- fold after $6 \mathrm{mg} / \mathrm{kg}$ in dogs with or without regional myocardial ischemia.

These kinetic studies emphasize the importance of drug concentrations at tissue sites of action in the myocardium in determining therapeutic concentrations of the drug. Our data ${ }^{18}$ suggest that the kinetics of electrophysiologic and antifibrillatory effects of bretylium parallel those of drug accumulation in myocardial tissue. In contrast, the kinetics of catecholamine release and serum concentration of drug are dissimilar. Furthermore, dissociation of the antifibrillatory effects of bretylium from its ability to block adrenergic neurons is demonstrated by the observation that protriptyline, a tricyclic antidepressant which prevents the accumulation of bretylium in adrenergic nerves thus preserving neuronal function, does not interfere with the antiarrhythmic effects. These studies demonstrated marked timeand dose-dependent differences in response to bretylium. Clinical extrapolation of these data as in other animal studies must be tentative, but do suggest the need for repeated acute drug dosing and allowance of greater time after acute bretylium dosing before assuming drug failure. ${ }^{19-24}$ The delayed response in the increase in the ventricular fibrillation threshold with small doses might be converted to an immediate response by a larger acute dose which results in a larger increase in the myocardial tissue concentration and electrophysiologic effects of the quaternary ammonium compound. ${ }^{10,11}$ The rapidity with which one can administer bretylium is limited, however, by its concomitant effects on the adrenergic neuronal stores of norepinephrine.

The June, 1983, issue of THE JOURNAL contains a report by Fujimoto et al., ${ }^{25}$ who assessed the electrophysiologic effects of intravenous bretylium upon the conduction of premature impulses and excitation threshold in normal and ischemic myocardium. Bretylium was found to decrease the disparity in conduction times between the normal and the ischemic myocardial tissue. These changes were associated with a delay in the conduction of impulses from normal myocardial tissue to the border of the ischemic heart muscle. In addition, bretylium also was noted to decrease the disparity between excitation thresholds of adjoining ischemic and normal myocardium. Of note was the observation that the significant effects of bretylium appeared to be late in onset (similar to the finding noted by our group $^{13,18}$ ), once again reflecting the time required to obtain a sufficient myocardial tissue concentration of drug to bring about a desired electrophysiologic effect. 


\section{THE ANTIARRHYTHMIC VERSUS ANTIFIBRILLATORY EFFECTS OF BRETYLIUM}

The two clinical reports ${ }^{6,7}$ presented in the May and June, 1983, issues of THE JoURNAL have failed to demonstrate the effectiveness of bretylium to prevent inducible ventricular tachyarrhythmia. Despite the fact that patients were given a continuous intravenous infusion of bretylium for 4 to 9 days, ${ }^{7}$ the associated release of catecholamines would be occurring and could have negated any beneficial directly mediated electrophysiologic effects of the quaternary ammonium drug. Whereas catecholamine release decays within 1 or 2 hours after a single dose, this is not the case with continuous or repeated bolus administration of bretylium. ${ }^{26}$

The inability to document a beneficial action of bretylium in the prevention of inducible ventricular tachyarrhythmia as reported by Bauernfeind et al. ${ }^{6}$ could, in effect, be attributed to the relative short duration between the administration of drug and the repeated efforts of programmed electrical stimulation. As discussed above, sufficient time may not have elapsed for myocardial tissue concentrations of the quaternary ammonium compound to have achieved an electrophysiologic effect. The inability of bretylium to prevent or suppress the induction of inducible tachyarrhythmia is not a unique observation, since amiodarone, which is reported to be effective for long-term therapy of recurrent ventricular tachyarrhythmias, does not prevent arrhythmias in response to programmed electrical stimulation. ${ }^{27}$ These findings for both bretylium and amiodarone, two class III agents, contrast with other observations which favor the concept that a drug that fails to prevent ventricular tachycardia in response to programmed electrical stimulation will also fail to prevent the spontaneous development of ventricular tachyarrhythmia or, more importantly, ventricular fibrillation. ${ }^{28}$ Thus the question which arises is what end point does one select to provide proof of efficacy with respect to the ability of a given drug to protect against the development of a lethal dysrhythmia? There is a need to achieve a better understanding of the manner in which bretylium, and related class III drugs, should be administered to patients who are at high risk of developing life-threatening dysrhythmias. It is becoming more apparent that the early arrhythmias associated with acute myocardial ischemia, and most likely with sudden coronary death, are due to a reentry mechanism whereas the late occurring arrhythmias are most likely due to enhanced or abnormal automaticity. ${ }^{2 y-32}$ It seems essential, therefore, in seeking a drug(s) that will prevent life-threatening dysrhythmias and sudden coronary death, that one conduct such studies in the early ischemic phase and record the associated electrical events.

The use of an electrophysiologic protocol for drug selection is based on several assumptions: first, that the tachycardia produced in the laboratory by programmed stimulation is identical to the clinical tachyarrhythmia; second, that the response to drug therapy in the laboratory predicts the clinical response; and third, that the ability to prevent the electrically induced ventricular tachycardia by drug treatment predicts the inability of the heart to develop ventricular fibrillation, especially if an ischemic episode superimposes upon a vulnerable substrate. Is the prevention of electrically induced arrhythmias by drug therapy synonymous with the prevention of sudden coronary death? Thus whereas the first and second assumptions may be established, the latter is not, since an acute ischemic episode is not part of the testing procedure and the true efficacy of an intervention can only be determined by looking at its potential to prevent sudden coronary death. Programmed electrical stimulation and acute pharmacologic testing may not be valuable in helping to identify those at risk of sudden coronary death and in establishing treatment regimens. The identification of a truly effective agent will be determined by its ability to prevent ventricular fibrillation, an end point seldom achieved during provocative testing procedures. It may also be true that a drug that fails to prevent the initiation of tachyarrhythmia by programmed electrical stimulation may still successfully prevent a spontaneous recurrence. This would be especially true of those agents which accumulate in myocardial tissue over time and show little correlation between concentration of drug in the plasma and therapeutic efficacy. Thus there is a need to reorient our thinking about the manner in which pharmacologic interventions may influence the final outcome in individuals at risk of sudden death due to disorders of ventricular rhythm. Since the lethal event is most often associated with ventricular fibrillation, it may be sufficient to have an agent which prevents the development of this electrophysiologic disorder even though it does not show an ability to prevent or to suppress completely the electrical induction of tachyarrhythmias.

A major problem in designing therapeutic approaches for the prevention of lethal ventricular dysrhythmias has been in the failure to use appropriate animal models which permit evaluation of the 
events occurring in the very first minutes of an ischemic episode superimposed upon a vulnerable substrate. The studies from our laboratory ${ }^{19}$ reported in the May, 1983, issue of THE Journal, provide experimental data to show that bretylium has an ability to prevent the development of ventricular fibrillation in response to an acute ischemic event at a site remote from a previous myocardial infarction. In drug-treated animals programmed electrical stimulation performed 12 hours after the last bretylium dose was no longer effective in initiating a tachyarrhythmia, an event which coincided with observed changes in the electrophysiologic properties of the heart, characterized by the druginduced prolongation in the effective refractory period.

Thus bretylium has been classified as belonging to a group of agents which are placed in class III because they have the property of increasing the action potential duration and prolonging the effective refractory period. In the ischemic heart, bretylium decreases the disparity in action potential duration that exists between normal and acutely ischemic regions. This action may account for the ability of bretylium to prevent the establishment of a reentry pathway and therefore protect against the initiation of ventricular fibrillation.

Because of the potential role of quaternary ammonium derivatives as antifibrillatory drugs, our laboratory has examined a number of agents using the conscious canine model with chronic myocardial ischemia and programmed electrical stimulation for the induction of reentrant ventricular tachycardia. The recent description of a new quaternary ammonium compound, clofilium, ${ }^{33,21}$ with electrophysiologic and antifibrillatory properties similar to those of bretylium, adds further support to the concept that drugs belonging to the members of class III may hold promise as specific antifibrillatory agents. The quaternary ammonium compounds, like bretylium and UM-272, are known to concentrate in normal and ischemic myocardium independent of their respective plasma concentrations. ${ }^{18,38-37}$ Substantial amounts are absorbed from the gastrointestinal tract, contrary to the erroneous notion that intestinal absorption of monoquaternary amines does not occur. $^{11,36,37}$

We have examined bretylium in a group of patients, each of whom has experienced one or more episodes of ventricular fibrillation. Initial therapy was instituted with intravenous bretylium and maintained with oral administration in dosages of 300 to $400 \mathrm{mg}$ every 8 hours. Repeated determinations of plasma and urinary concentrations of bre- tylium have confirmed the fact that the drug is absorbed after oral administration. ${ }^{37}$ Although our series of patients is small, the fact that the patients remained free of life-threatening arrhythmias would suggest that bretylium as well as other quaterenary ammonium compounds deserve to be considered as potential antifibrillatory agents in the hope of reducing the incidence of sudden coronary death. If this proves to be the case, then there will be reason for optimism.

The recent studies with aminodarone provide additional reason for hope that new therapeutic interventions which depart from the typical class I antiarrhythmic drugs may provide the proper electrophysiologic effects, so that the once vulnerable substrate presented by the ischemically injured myocardium becomes electrically more stable during the superimposition of a subsequent ischemic event, therefore preventing the induction of a reentrant rhythm and the development of a lethal arrhythmia. ${ }^{22}$

Substantial progress has undoubtedly been achieved in recent years with respect to identifying subsets of patients who are at risk of sudden coronary death. Both surgical and electrical means of preventing sudden death in the most difficult to manage patient groups have been attempted with impressive results. However, the national need continues to demand that an increased priority be given to the development of more reliable and effective therapeutic agents capable of preventing ventricular fibrillation. The challenge is formidable, but is one which can be met through the concerted efforts of basic and clinical investigators, respectively employing relevant animal models for the preclinical testing of potential therapeutic interventions and appropriate end points to determine clinical efficacy in a patient population known to be at an increased risk of dying suddenly and unexpectedly due to ventricular fibrillation.

\section{REFERENCES}

1. Yu PM: Prehospital care of acute myocardial infarction. Circulation 45:189, 1972.

2. Warren JB: Recurrent "sudden death" (Editorial). N Engl J Med 293: 298, 1975.

3. Lovell RRH: Arrhythmia prophylaxis: Long-term suppressive medication. Circulation 51:III-236, 1975.

4. Zipes DP, Troup PJ: New antiarrhythmic agents. Am J Cardiol 41:1005. 1978.

5. Cardinal R, Sasyniuk BI: Electrophysiologic effects of bretylium tosylate on subendocardial Purkinje fibers from infarcted canine hearts. J Pharmacol Exp Ther 204:159, 1978.

6. Bauernfeind RA, Hoff JV, Swiryn S, Palileo E, Strasberg B, Scagliotti D, Rosen KM: Electrophysiologic testing of bretyl ium tosylate in sustained ventricular tachycardia. AM HEART J 105:973, 1983.

7. Greene HL, Werner JA, Gross BW, Sears (iK: Failure of 
bretylium to suppress inducible ventricular tachycardia. AM HEART J 105:717, 1983.

8. Boura ALA, Green AF: Actions of bretylium: Adrenergic neuron blocking and other effects. Br J Pharmacol 14:536, 1959 .

9. Chatterjee K, Mandel WJ, Vyden JK, Parmley WW, Forrester JS: Cardiovascular effects of bretylium tosylate in acute myocardial infarction. JAMA 223:757, 1973.

10. Anderson JL, Patterson E, Wagner JG, Johnson TA, Lucchesi BR, Pitt B: Clinical pharmacokinetics of intravenous and oral bretylium tosylate in survivors of ventricular tachycardia or fibrillation. Clinical application of a new assay for bretylium. J Cardiovasc Pharmacol 3:485, 1981.

11. Woosley RL, Reele SB, Roden DM, Nies AS, Oates JA: Pharmacologic reversal of hypotensive effects complicating antiarrhythmic therapy with bretylium. Clin Pharmacol Ther 32:313, 1982.

12. Patterson E, Gibson JK, Lucchesi BR: Prevention of chronic canine ventricular tachyarrhythmias with bretylium tosylate. Circulation 64:1045, 1981.

13. Patterson E, Gibson JK, Lucchesi BR: Postmyocardial infarction reentrant ventricular arrhythmias in conscious dogs: Suppression by bretylium tosylate. J Pharmacol Exp Ther 216:453, 1981.

14. Anderson JL, Brodine WN, Patterson E, Marshall HW, Allison SD, Lucchesi BR: Serial electrophysiologic effects of bretylium in man and their correlation with plasma concentrations. J Cardiovasc Pharmacol 4:871, 1982.

15. Wit AL, Steiner C, Damato AN: Electrophysiologic effects of bretylium tosylate on single fibers of the canine specialized conduction system and ventricle. J Pharmacol Exp Ther 123:344, 1970

16. Bigger TL $\mathfrak{J}$, Jaffe CC: The effect of bretylium tosylate on the electrophysiologic properties of ventricular muscle on Purkinje fibers. Am J Cardiol 27:82, 1971.

17. Bernstein JG, Koch-Weser J: Effectiveness of bretylium tosylate against refractory ventricular arrhythmias. Circulation 45:1024, 1972.

18. Anderson JL, Patterson E, Conlon M, Pasyk S, Pitt B, Lucchesi BR: Kinetics of antifibrillatory effects of bretylium: Correlation with myocardial drug concentrations. Am J Cardiol 46:583, 1980

19. Holland K, Patterson E, Lucchesi BR: Prevention of ventricular fibrillation by bretylium in a conscious canine model of sudden coronary death. AM HEART J 105:711, 1983.

20. Patterson E, Holland K, Eller BS, Lucchesi BR: Ventricular fibrillation resulting from ischemia at a site remote from previous myocardial infarction. A conscious canine model of sudden coronary death. Am J Cardiol 50:1414, 1982.

21. Kopia GA, Hess TA, Lucchesi BR: The antifibrillatory actions of clofilium in the ischemic canine heart (abstr). Circulation 64:IV-124, 1981.

22. Patterson E, Lucchesi BR: Ventricular fibrillation in a conscious canine model of sudden coronary death-Prevention by chronic amiodarone therapy. Circulation 66:II-132, 1982.
23. Patterson E, Lucchesi BR: Antifibrillatory actions of the beta-adrenergic receptor antagonists, nadolol and sotalol. Circulation 66:II-131, 1982.

24. Eller BT, Patterson E, Lucchesi BR: Ventricular fibrillation in a conscions canine model-Its prevention by UM-272. Eur J Pharmacol 87:407, 1983.

25. Fujimoto $T$, Hamamoto $H$, Peter $T$, McCullen A, McCullen A, Melvin N, Mandel WJ: Electrophysiologic effects of bretylium on canine ventricular muscle during acute ischemia and reperfusion. AM HEART J 105:966, 1983.

26. Lucchesi BR: Antiarrhythmic drugs. In Antonaccio M, editor: Cardiovascular pharmacology. New York, 1977, Raven Press, p 269.

27. Heger JJ, Prystowsky EN, Jakman WM, Naccarelli GV, Warfel KA, Rinckenberger RL, Zipes DP: Amiodarone: Clinical efficacy and electrophysiology during long-term therapy for recurrent ventricular tachycardia or ventricular fibrillation. N Engl J Med 305:530, 1981.

28. Horowitz LN, Josephson ME, Farshidi A, Spielman SR, Michelson EL, Greenspan AM: Recurrent sustained ventricular tachycardia. 3. Role of the electrophysiologic study in selection of antiarrhythmic regimens. Circulation 58:986, 1978.

29. Scherlag BJ, El Sherif N, Hope R, Lazzara R: Characterization and localization of ventricular arrhythmias resulting from myocardial ischemia and infarction. Circ Res 35:372, 1974 .

30. Lazzara R, El Sherif N, Scherlag B: Early and late effects of coronary artery occlusion on canine Purkinje fibers. Circ Res 35:391, 1974.

31. F'riedman P, Stewart JR, Fenoglio JJ Jr, Wit AL: Survival of subendocardial Purkinje fibers after extensive infarction in dogs: In vitro and in vivo correlations. Circ Res 33:597, 1973.

32. Horowitz LN, Spear JF, Moore EN: Subendocardial origin of ventricular arrhythmias in 24-hour-old experimental myocardial infarction. Circulation 53:56, 1976.

33. Steinberg MI, Malloy BB: Clofilium, a new antifibrillatory agent that selectively increases cellular refractoriness. Life Sci 25:1397, 1979.

34. Gibson JK, Korn NL, Counsell Re, Lucchesi BR: Tissue distribution and antiarrhythmic action of N-dimethylpropranolol (UM-272) in the dog. Fed Proc 38:697, 1979.

35. Patterson E, Stetson P, Lucchesi BR: Sensitive gas chromatographic assay for the quantitation of bretylium in plasma, urine and myocardial tissue. J Chromatogr 181:33, 1980.

36. Patterson E, Stetson P, Lucchesi BR: Plasma and myocardial tissue concentrations of UM-272 (N,N-dimethylpropranolol) after oral administration in dogs. J Pharmacol Exp Ther 214:449, 1980.

37. Anderson JL, Patterson E, Wagner JG, Stewart JR, Behm HL, Lucchesi BR: Comparative disposition of oral and intravenous bretylium in man. Clin Pharmacol Ther 28:468, 1980 